\title{
Traveling Machines and Colonial Times
}

Machines de voyage et temps coloniaux

Maquinas de viaje y tiempos coloniales

\section{Simon Schaffer}

\section{(2) OpenEdition}

\section{Journals}

Electronic version

URL: https://journals.openedition.org/assr/46165

DOI: $10.4000 /$ assr.46165

ISSN: $1777-5825$

Publisher

Éditions de l'EHESS

Printed version

Date of publication: 31 October 2019

Number of pages: 171-190

ISBN: 9782713227844

ISSN: 0335-5985

\section{Electronic reference}

Simon Schaffer, "Traveling Machines and Colonial Times", Archives de sciences sociales des religions

[Online], 187 | juillet-septembre 2019, Online since 07 January 2022, connection on 08 January 2022 URL: http://journals.openedition.org/assr/46165 ; DOI: https://doi.org/10.4000/assr.46165 


\title{
Simon Schaffer
}

\section{Traveling Machines and Colonial Times}

\author{
"The British rulers of India are like men bound \\ to make their watches keep time in two longitudes \\ at once. Nevertheless, this paradoxical position must \\ be accepted. If they are too slow, there will be no \\ improvement. If they are too fast, there will be no security." \\ Henry Maine, The effects of observation of India on modern \\ European thought, 1875
}

\section{Time machines}

We have been invited to explore claims that knowledge and belief are inevitably and productively entangled. It is suggested that this kind of interweaving is peculiarly evident and important in work with objects that somehow respond to and register invisible forces, powers otherwise beyond observation and experience. Many devices have been charged with such a function. Machines that register and manage time seem peculiarly apt for consideration. The relation between knowledge and belief has a clear temporal dimension. Current knowledges are often used as standards against which past knowledge claims are dismissed, or appreciated, as systems of belief. It is as though the contrast between reliable engagement with nature and the worlds of cultural belief turns into a contrast between the future and the past. It is often claimed as part of the celebration of scientific modernity that as time passes culturally generated beliefs are systematically displaced by delocalised knowledge (Latour, 1991: 97).

The machineries of time, both as measure and as travel, offer peculiarly perspicuous technologies that engage with, and register, invisible powers otherwise beyond experience. It seems peculiarly important to attend to such time machines in settings of cultural encounter and engagement, since it has often been supposed that temporal devices embody and reinforce specific cultural systems and cannot function outwith such networks. Stories of colonial mobility and imperial regimes are well stocked with anecdotes of 
the indispensable role of time systems, and the use of temporal technologies as means of translating between, and exercising power over, a range of social orders. In Lilliput, Gulliver's pocket watch was taken by the natives to be his God: so in stories of the colonial encounter it was repeatedly related that indigenous observers took such instruments as signs of power, and the uncanny ability to predict celestial events such as eclipses as a kind of omnipotent magic. When the pre-eminent missionary and colonial agent David Livingstone prepared for his expedition across northern Botswana and the Zambesi in 1853 , he made the significant decision to stash in one specially insulated case the three texts on which his survival apparently depended: the Bible, the Nautical Almanac, and the Table of Logarithms. These were closely related ways of managing his time. With advice from astronomers in London and Cape Town, he learnt how to use a fine Dent chronometer and a Troughton sextant. The hardware's use dominated racist and imperial imaginaries. In the epoch of high imperialism, such effective machines and predictions fictively worked to win victory for the otherwise desperate modern protagonists over hostile southern Africans in Rider Haggard's King Solomon's Mines (1885) and over primitive medieval knights in Mark Twain's A Connecticut Yankee at King Arthur's Court (1889) (Nanni, 2012: 29, 122; Livingstone, 1857: 230231). The question of time's magic was salient. Programmes that subjected, examined and historicised the colonised populations often did so, precisely, in the name of a story of the displacement and redemption of a degenerate past by imperial modernity. There was a close association between the denunciation of superstition and of magical belief and the deployment of time devices and exquisite instrumentation that could allegedly demarcate knowledge from belief (Perkins, 2001).

Attention to the material devices, instruments and related hardware made of ivory and brass, wood and glass, used as time machines in colonial programmes, helps illuminate these problems of asymmetric demarcation and power. Often commissioned and funded as central aspects of the military budgets of European imperial organisation from at least the epoch of the sixteenth century Catholic Monarchy, the equipment that was used to record and manage time was always a major component not only of precision measures, but of the capacity to travel, to sustain a militant presence, and to organise relations across and within cultures elsewhere. According to Serge Gruzinski, in his comparative study of the Tarih-i-Hind Garbi composed in Istanbul around 1580 as an account of the Americas, and the account of the Ottoman empire written by the cosmographer and printer Heinrich Martin in Mexico in 1606, Reperterio de los tiempos, this was when, for the first time, European experts employed as colonial officers managed to use their hardware to carry out co-ordinated and putatively simultaneous operations across the globe: administrative simultaneity was a vital aim and practical interest of the new time machines deployed across these regimes (Gruzinski, 2010: 29-30).

Several features of these machines' use are thus important: the work of making reliable knowledge, in which time machines were understood as 
mediators between users and the world; and the work of making knowledge communities, in which such instruments were understood as mediators between different users. It is a familiar lesson of the history of the sciences that these uses depended on each other; solutions to the problem of knowledge are solutions to the problem of social order. As Marilyn Strathern has argued, such devices never simply illustrated nor brought to presence sets of meanings that could somehow be spelt out in other ways. The view that interpretation should best treat such objects as mere illustrations, she pointed out, helped divorce social anthropology from the study of material culture; and exactly the same could be charged against histories of the sciences that reckoned such chronometric devices offered little save "background information" about elegant and celebrated scientific theories. But social orders offer conventions with and against which users improvise, by reworking or revising the objects with which they live (Strathern, 1990: 38).

Such work of improvisation and adaptation was performed by hardware carried by travelers, experts, administrators and merchants, especially in moments of encounter and exchange (Newell, 2010: 49-51; Smith, 2010). Long before the celebrated voyages of the European Enlightenment and its imperial aftermaths, Portuguese navigators trained by Islamic and Jewish experts in the rule of the astrolabe had claimed possession of the lands of the Tupinamba or the Monomatapa by ceremonially enacting astronomical determinations of position, their cross-staffs and quadrants helping vouch for these lands' place and time in their tale of conquest. European mariners off course in the spaces of the Indian Ocean found that they were already mastered by locally expert traders, observers and travelers whose knowledge and skill proved decisive as resources and obstacles, while Jesuit missionaries were exceptionally ingenious in mobilising temporal hardware worldwide in networks they helped make and reinforce (Seed, 1995: 128-148; Subrahmanyam, 1993; Harris, 1998). The technological ensembles of eighteenth-century navigation were admittedly novel, involving marine chronometers, lunar almanacs, quadrants, theodolites, sextants and sophisticated compasses, but just as charged with these symbolic and practical significances (Glennie, Thrift, 2009: 280-297, 336-350; Despoix, 2005: 46-65). It has been argued, not always convincingly, that ships then functioned as so many scientific instruments, as in European journeys into the Pacific and their reception by Polynesian navigators. According to Bernard Smith, the "construction of reliable chronometers" carried by vessels which combined the virtues of "the laboratory and the fortress" meant that the "archipelagos of the Pacific yielded information of value to the ocean-going scientist" with what he claimed was unprecedented ease (Smith, 1985: 2; compare Raj, 2000). The indispensable information provided to James Cook by the Tahitian expert Tupaia, for example, was then calibrated against the times recorded and apparently well established by British astronomers and their equipment. As Anne Salmond has argued, however, much was also lost or blocked in these kinds of encounters. Tupaia never mastered European 
navigational instruments, while Europeans simply didn't manage to make good sense of Polynesian maritime knowledge. In such cases time machines and their expert specialists often failed quite to sustain effective encounters, and "the translational task was too difficult" (Salmond, 2005: 182).

Such problems of translation in encounter, and, more generally, the intricate relation between translation in space and the measure of time, have long dominated the very definition of the work of anthropology and of history in their dealings with cultural variation in colonised settings. There was a fundamental instructive relation between the use of chronometric technologies by expert specialists and the claim that to travel to so-called exotic territories was to travel back in time. The notorious formulation was composed by the idéologue Joseph-Marie de Gérando in September 1799 as part of the briefing documents for a survey expedition led by Nicolas Baudin to Australasia and the south Pacific (Stocking, 1964; Moravia, 1967: 964; Douglas, 2014). This was a decisive exercise in the mobilisation of European scientific hardware and personnel in the region. Rather than pursue his South American enterprise, Alexander von Humboldt energetically but abortively lobbied to take his vast collection of clocks, sextants, telescopes, and meteorological devices on Baudin's voyage (Humboldt and Bonpland, 1814; Buschmann, 2014: 188-192).The expedition's deployment of Edmé Régnier's newfangled dynamometer to determine the relative physical strength of indigenous and European populations represented a peculiarly clear case of the use of credible machinery to bring invisible forces to presence, then to use those forces to calibrate the virtue of contrasted cultures. It was argued by the French voyagers that instrumental data that showed Tasmanians were typically dynamically weaker were the more reliable, precisely because indigenous populations were so uniform, while European peoples were intrinsically varied (Péron, 1994; Hughes, 1990).

De Gérando's memoir for the expedition already pithily explained that to make such a journey was to travel into the atavistic human past. "The philosophic traveler who sails to the ends of the Earth, is in fact journeying through the sequence of ages, he travels into the past; every step he takes is a century he traverses." He made a rather direct contrast between the virtues of such chronogeography and the vices of the Egyptomania that flourished in the wake of Constantin Volney's Les ruines (1791) and the 1798 Egyptian expedition. De Gérando composed his memoir at exactly the same time as Bonaparte's hurried return to France from Egypt, where the military commander had famously appealed to the 'forty centuries' that gazed down from the Pyramids on his troops. In response, De Gérando taught that Pacific islanders "who scorn our ignorant vanity, reveal themselves as antiquities and majestic monuments of the origin of time; monuments much more than a thousand times worthy of our admiration and respect than those famous pyramids on which the banks of the Nile pride themselves. The latter only attest to the frivolous ambition and transient power of some individuals whose very name has scarcely come 
down to us; the former retrace for us the state of our own ancestors, and the first history of the world". ${ }^{1}$

The notion that fieldwork is time travel, dependent on the traveler's machinery, has since dominated reflexion on the anthropology of knowledge and belief, even and particularly when those reflexions take the form of critique. In a remarkable lecture on anthropology's scope given at the Smithsonian Institution in 1965, Claude Lévi-Strauss pondered the twin challenges of "the high rate of extinction afflicting primitive tribes" and "the distrust in which traditional anthropology is held" by "peoples who prefer to look at themselves as temporarily backward rather than permanently different" (LéviStrauss, 1966: 125). Both extinction and development, two forms of capitalist intensification, thus seemed major problems for his science. Significantly, Lévi-Strauss chose an astronomical metaphor to demand investment in salvage ethnography's time machinery. He imagined an unknown planet within observational range for a few decades. Surely there would be support for purpose-built "telescopes and satellites" to study it. How much more important to invest in the study of "native cultures [that] are disintegrating faster than radioactive bodies; and the Moon, Mars and Venus will still be at the same distance from the Earth when that mirror which other civilizations hold up to us will have so receded from our eyes" that they would become invisible, "however costly and elaborate the instruments at our disposal" (Lévi-Strauss, 1966: 127). The role of time machinery in anthropology's fate was even clearer in an exactly contemporary remark by Ernest Gellner, reflecting on the transition from evolutionary to structural-functional modes in anthropology. In 1964 he explained how "systematic study of primitive tribes began first in the hope of using them as a kind of time machine", a journey into the past of the cultures of those doing the studying; yet even after the abandonment of evolutionary historicism, "this supposed time machine was used with redoubled vigour" (Gellner, 1964, cited in Fabian, 2002: 39). The image stayed common in Gellner's comments on the transition from evolutionism. A much later remark, posthumously published, on "the rich and rapidly growing mass of ethnographic literature" accumulated by colonial administrators and evolutionist ethnographers simply labeled such material as "the new time machine" (Gellner, 1998: 115).

No doubt the prevalence of this imagery of time machinery helps make sense of a familiar paradox in studies of different time cultures. As articulated most powerfully by Johannes Fabian, it is charged that anthropology has systematically asserted that contemporary peoples are in fact occupants of an ancient past: anthropology's political crime includes the denial of a commonly shared time. Yet historians of colonial regimes have apparently charged the opposite: imperialism's political crime includes the imposition of a commonly

1. Gérando, 1994: 76. For characteristic citations, see Fabian, 2002: 6-7; Fornasiero, Monteath and West-Sooby, 2004: 354-355. 
shared time (Fabian, 2002: 153-154; Nanni, 2012: 10). A canonical case is provided by accounts of encounters between Australian aboriginal and settler communities. Settlement and appropriation depended on the mobilisation of the military technologies of a time measurement and chronometric navigation: the establishment of an astronomical observatory and pendulum clock at Sydney Cove during the construction of the first penal colony in 1788 has been described as a sign of "the permeation of the entire world by the European time spirit". In his account of Australian time cultures, Graeme Davison also points out that the very phrase "doing time", as an expression of the length of a prison sentence, was born in the Australian penal colony. The devices of time measurement were thus sites of resistance and contestation, of dominance and power over what might other escape surveillance. Most importantly, the machines that determined time were also understood very widely as devices for disciplining the soul - time thus measured became a form of redemption (Davison, 1993: 12, 16).

This is why an interest in the techniques and devices that produced beliefs and captured otherwise invisible powers is so valuable: especially if it includes attention to the use of such devices in moments of encounter and exchange. Historians of time technologies in colonial and imperial settings have shown clearly how there was a form of temporal conversion, in which different chronologies and different chronometric machinery could be used as a kind of calibration, judging cultures according to the presence or absence of temporality and punctuality as understood within the dominant cultural power. It was never the case that aboriginal cultures were timeless, and instead exercised sophisticated and alert senses of judgment of time and season. But they were judged timeless by colonial powers, and thus assigned to a time immensely prior to the time these powers sought to master. Historians of colonial time have also shown how uneven, how contested, and how fractured were these forms of dominance. Time machines were almost always sites of conflict and of challenge, allowing the development of a range of contrasted senses of time and of chronological belief systems (Nanni, 2012: 29; Perkins, 2001: 94-97; McNeil, 2001).

\section{Encountering clocks}

In what follows, the relationship between the machinery of time measures, encounters across cultures, and the roles of exchange and encounter in making sense of how belief is defined are explored in the cases from the later eighteenth century southern Pacific, one of the key regions where such debates were developed and analysed. It was in this field that some of the most celebrated and sacred objects of European time culture were tried out and where some of the most sophisticated systems and practices of indigenous time cosmology, in Polynesian navigation and in Melanesian networks, were to be found. Every marine chronometer, for example, functioned only because of the integrity of all the encounters between instruments and others, including 
makers, mariners and islanders. The life of James Cook's so-called "trusty friend" K1, the copy of John Harrison's sea watch completed by Larcum Kendall in 1769 , shows how these processes worked. It's been tempting to treat these devices as magnificently autonomous, associated with a single maker and somehow capable of working permanently and in solitude as guides and indicators. That is why such devices so often appear in hagiographic stories of the effortless victory of European time sense. The temptation must be resisted. These instruments were personified, they were the heterogeneous results of widely distributed labour and sociability, they prompted and frustrated the hard work of maintenance, exchange and collaboration. Their work entirely relied on their place within very intense socially negotiated networks (Dunn and Higgitt, 2014: 131-133). In 1772, charged with proving Kendall's watch in the Pacific, the British Board of Longitude instructed the astronomers William Wales and William Bayly that the "watch machines" be held in a box secured by three separate locks. This was a measure otherwise typical of rituals for storing coins at the Royal Mint or sacred wafers for the eucharist. On board Cook's Resolution, keys were held by the commander, by the first lieutenant Charles Clerke and by Wales, who would thus act as witnesses of how the watch was wound up and its rate calibrated against a regulator or astronomical clock when on land. These rules and catalogues were ideals if not realities. In late January 1774 , so Wales recorded, a midshipman had entered his cabin, mishandled the astronomer's stopwatch, dropped it and broke the ruby cylinder. In April 1779 , on the Siberian coast at Petropavlovsk, where the British had arrived in the wake of Cook's death on Hawai'i, a watchmaker's apprentice drawn from the crew was commissioned to try to fix $\mathrm{K} 1$ which "in its present state was totally useless". For these devices to work at all, complex social encounters had simultaneously to be organised, policed and recorded. ${ }^{2}$

The significance of these encounters and the management of the instruments was exemplified during the arrival of the Resolution at Tanna in Vanuatu in August 1772, a fraught period of desultory trade and constant threats of violence that culminated in the killing of a Tannaese inhabitant by one of the crew (Thomas, 2003: 240-243). Wales' orders implied he should bring the watch to shore and check its rate of going against an astronomical clock and by making observations of the Sun at equal altitudes before and after noon. He made prudent calculations about the safety of carrying the Kendall through the surf, staying under guard and avoiding an overnight vigil on land. "There was no way but by signals and those must go through three hands beside my own... I resolved to venture the watch on shore the first $\&$ last day and be as carefull as possible in the others, being certain of one steady hand to assist me always in it". Within a day or two Wales had ventured up the beach with the Kendall and his one foot radius astronomical quadrant, a carefully

2. Beaglehole, 1961: 723-724 for the triple locks; J.C. Beaglehole, University Library Cambridge MS RGO 14/58, fol. 84v (27 January 1774) for the damaged stopwatch; Beaglehole, 1967: 678, n. 1 for Petropavlovsk. 
miniaturised version made by John Bird of the large devices with which Wales had been trained by the Astronomer Royal Nevil Maskelyne at Greenwich. On successive days much work was lost. It was painful labour moving the hardware, trusting to clear skies and establishing prudent relations with the islanders: "this way of going to work is very inconvenient... I have no way of spending my time but in sauntering to \& from the Beach". Wales decided to organise expeditions into the interior: "as I could neither leave the beach where my instruments were nor get on board I got some natives to throw their spears at two stakes which had been driven down to fasten the boats." More intense exchanges and somewhat better measures followed (Beaglehole, 1961: 855-857). Wales would later vaunt his expertise in such encounters, instructing the young William Gooch in 1791 on the value of iron axes in establishing profitable trade across the Pacific. The instruments these men managed both relied on, and enabled, the ways these encounters developed. ${ }^{3}$ Just as Cook would later go back over the events at Tanna carefully to reorder the events around the islander's death there in the name of a literary image of humanity, while debates about apparent Tannaese indifference to European artefacts would much concern the men who made these accounts, so the accounts of the voyage would afterwards be reconstructed in the name of a technical efficacy so that it would decisively seem that the Kendall sea watch could be trusted and celebrated as an utterly reliable and autonomous wayfinder: "Mr Kendall's Watch has been our faithful guide". This was the widely trumpeted result rather than the necessary precondition of the accounts and encounters with agents and instruments on the voyage. ${ }^{4}$

An over-literal reading of the immense paperwork of charts, logbooks and catalogues accumulated during and in the wake of these voyages, now stored in well-curated libraries and museums, has reinforced the notion that European projects in the later eighteenth century involved something like an impersonal and decontextualised form of knowledge and practice, intent on elimination more than encounter. According to this version of events, it has seemed as if the disturbingly messy materialities of the instruments and techniques used on board and on the beach were to be denied or suppressed in the name of an objective and mathematical survey. The longitude schemes first adopted in the Pacific during Cook's voyages from 1768, dependent on highclass chronometers like K1, precisely graduated sextants and mass-produced printed almanacs of the position of Moon and stars, have therefore been read as though they imposed an abstract net on a navigable and thus controllable world. Anne Salmond evokes the power exercised by the European navigators off Tahiti, "charting the islands and surrounding ocean, transmuting them into a space gridded by lines of latitude and longitude, stripped of substance and emptied of people". In a compelling analysis of the introduction of the

3. Gooch to his parents, 17 June 1791, University Library Cambridge MS Add Mm.6.48, fol.40v. 4. Thomas, 2003: 257-258; Guest, 2007: 116-117; Cook to Admiralty, 1775, in Howse, 1969: 194. 
formalised logbook on these 18 th century voyages, Philippe Despoix remarks that the regimentation of instrumental procedures and the maintenance of journals in standard form had as its goal the forging of "an exact geography". As a result of this enterprise, he claims, such lists, charts and journals "in the end constituted the ever more depersonalised medium of an exploration defined as an observational procedure guided and instructed in every one of its details" (Salmond, 2005: 169; Despoix, 2005: 77-79; compare Thomas, 2003: 7).

This was an important part of an enlightened utopia: but it therefore happened absolutely nowhere. Such devices were always on trial, never selfevidently reliable unless and until they were in regular use and integrated into the hierarchical social networks that governed them. So when the marine officer William Dawes was commissioned as astronomical observer for the first convict fleet sent to Australia in 1787, his Portsmouth colleagues Bayly and Wales at once began trying his indispensable sextant, the key device for determining altitudes of Sun, Moon and stars on shipboard. There was a fault in the instrument that the pre-eminent London maker Jesse Ramsden had provided: "Mr Ramsden will allow a defect in the instrument whatever his opinion may be now". The troublesome instrument was sent back to London, travelling to and fro until the marine was somewhat mollified. Yet "it is impossible to foresee what imperfections may be discovered in the present construction or what improvements may be made in it in the course of several years", Dawes sagely observed. ${ }^{5}$

Such instruments travelled very widely, often much further than any of their users. In these travels, devices were treated as so many active agents, in need of coaxing, care and appeasement. Encounters thus involved makers, practitioners and instruments in complex negotiations. At Unalaska in the Aleutians in October 1778, for example, Cook presented the influential Russian trader Gerasim Izmaylov with a precious Hadley's octant, a version of a sextant with two mirrors that could determine celestial altitudes up to ninety degrees. Izmaylov had studied navigation at Okhotsk: Cook reported on his astronomical competence and that "altho' it was the first he had perhaps ever seen, yet he made himself acquainted with most of the uses that Instrument is capable of in a very short time". The instrument proved helpful in the encounter. Cook got hold of Russian charts of the northern Pacific and aid with his project. No doubt the status attributed to such devices, and the roles they played in newfangled repertoires of practice and measurement, was of considerable significance (Beaglehole, 1967: 457; Svet and Fedorova, 1978: 7-8; Werrett, 2004: 181-183).

One of the central components of these repertoires was the set of astronomical regulator clocks that were supposed to be landed whenever astronomers needed reliable timekeepers to rate their sea watches and

5. Dawes to Maskelyne, 16 January, 25 January and 8 February 1787 , Cambridge University Library MS RGO 14/48 fols. 242r, 249r and 252; Laurie, 1988: 471. 
record positions of planets, stars and satellites. Across the decades these pendulum-driven and rigidly engineered regulators, made by John Shelton, moved around the world in company with the mariners: across Britain and the north Atlantic, to the Cape, Australasia and the Pacific. They survive in metropolitan collections as eloquent relics of these displacements and their troubles. They were carefully engraved with the original length marked on the pendulum at Greenwich, a mobile sign of their accuracy to which their users were supposed to attend with exquisite precision. Wales recorded that such marks could aid the painful work of getting the clock back to its proper rate. The ordered accounts demanded these regulators be set in unusually firm bases on the beach (Beaglehole, 1961: 726; Howse and Hutchinson, 1969; Wales and Bayly, 1777: xi-xii). At Sydney in 1790, so Dawes reported back to Maskelyne, his clock was "wedged into a niche in the solid rock which has never been moved since the foundation of the world". Dawes' regulator had already travelled with Bayly on Cook's second and third voyages, while the regulator that went with Wales in 1772-75 then travelled on the Resolution in 1776-80. The fundamental act performed with these clocks was the eye-andear method, as it was baptised, to track the motion of a star or planet across the cross wires of a telescope's eyepiece while simultaneously listening to the beats of the regulator's pendulum. This was not simple even in the seclusion of Greenwich, and there generated very controversial results, but as Wales complained was even harder "to us whose Observatories stood generally on the sea shore, where the roraing of the surf seldome permitted us to hear the Astronomical Clock all the time it was going". 6 To make such mobile and fragile devices into temporary fixtures was, precisely, to turn a remote, transient and vulnerable site into the equivalent of a valid astronomical observatory and socially authoritative site. "If you could see it you would say it could not be better fixt". At his Sydney base, built by convict labour, Dawes then pursued not only astronomical observations but encounters with Eora informants as part of his work to record both celestial observations and indigenous vocabulary. If this was indeed an instantiation of some kind of "European time spirit", then it is crucial to recognise the labour, the engineering and the cosmologies on which that vision locally depended (Laurie, 1988: 476; Nathan, 2009: VI-VII).

Puzzles of maintenance and reliability were pervasive. Wales' inventories and accounts helped alerted his colleagues to the immense labour required to preserve and discriminate their devices' behaviour during such encounters. He developed ingeniously improvised means to secure the regulators on a cast iron block set on wooden piles, so as to accelerate the work of fixing them on the beach (Wales and Bayly, 1777: XI-XII). What mattered most was the recognition that these instruments had lives. To make them function it was

6. Dawes to Maskelyne, 16 April 1790, Cambridge University Library, MS RGO 14/48, fol. 300v; Howse and Hutchinson, 1969: 285; Wales and Bayly, 1777: XIX. 
essential to go back over those careers, write their biographies, and thus turn them through a kind of redemptive archaeology into ideal machines. Regulators were exquisitely sensitive to position, since pendulum rates depended on local gravity and on climatic conditions. Wales was exceptionally disturbed that his Shelton ran much faster at the Cape of Good Hope in November 1772 than in April 1775. He went back through his records of encounters with other mariners, with officers, with the instruments. He first supposed that the pendulum spring must have deformed. Then he decided he'd erred when setting up the regulator either at the Cape or at Dusky Bay in Aotearoa-New Zealand. He combed records and inventories for signs of disturbance or interference. He recorded the appalling fact that at Tahiti in late April 1774 "some witty gentleman or other found means to open it, and put the clock a minute back, I suppose, to try whether or no the Astronomer could find it out". Compensating by appeal to these parasites and misfortunes, it could then be claimed that "this clock will have agreed with itself as near, perhaps as must ever be expected for any clock to do". Decisive, so Wales urged, was storage, his precious stock "put away in damp and improper places as will ever be the case on board ships" (Wales and Bayly, 1777: XV-XVI).

Storage stayed a major difficulty. With Bayly's backing, Dawes grumbled that since his cabin was so far from that of the First Fleet's commander, Arthur Phillip, it was wrong that the senior officer should control access to all his equipment. At the Cape, the expedition's commander refused to let Dawes land any of the instruments. Dawes told Maskelyne that his precious sea watch, K1, the instrument that had travelled with Cook in the 1770s, had stopped because the Captain had not been able "to get down at noon to wind it up". 7 Encounters with such travelling instruments, catalogued and documented, coaxed and corrected, need therefore also to be understood through their somewhat complicated role as cargo. They often functioned as desirable objects of trade and appropriation. Notorious was the taking of the John Bird astronomical quadrant used to check the rate of the Shelton regulator on the beach during the observations of the Venus transit at Tahiti in May 1769. The entire transit programme there was dependent on intricate relations involving British and Polynesian protagonists and their devices. While on Irioa the ari' i rahi Te Pau (nicknamed "Lycurgus" by Banks) observed the transit with Banks and the clockmaker Spöring, the principal observatory at Fort Venus, manned by Cook and his astronomer Charles Green, became a stoutly defended exclusion zone. It is significant that when the Bird quadrant stored there nevertheless disappeared, compromising the astronomical enterprise, Banks first guessed that it might have been stolen not by Tahitians but by British mariners, being "supposed to contain nails or some kind of traffick". Significant, too was the rapidity with which Green, Banks and Spöring improvised stopgap repairs

7. Dawes to Maskelyne, 28 December 1786 and 10 July 1788, Cambridge University Library MS RGO 14 fols. 239v, $283 \mathrm{v}$. 
when the quadrant was recovered with Te Pau's aid (Beaglehole, 1963: 268270, 309; Green and Cook, 1771: 397-398). Crucial here was the broad range of meanings and stories embodied in such devices. Fraught relations with the fighting chief Tutaha, militant rival of Te Pau's lineage and humiliatingly held hostage by Cook against the quadrant's return, were tentatively re-established with exchange of pigs and axes. Bird's instrument played a central role in these encounters and exchanges, a function and status inseparable from its role in astronomy and time keeping (Thomas, 2003: 66-67). Just as it was necessary to go back over and fix the challenging social relations on the island, so it proved crucial to go back over and explain the errant data from the quadrant. In defence against Maskelyne's fierce criticism of his astronomical observations, Cook riposted that the Astronomer well knew that the Bird had been "pulled to pieces and many of the parts broke which we had to mend in the best manner we could before it could be made use of" (Beaglehole, 1961: CXLIV-CXLV; Turnbull, 1998: 124).

Such tales became notorious in the retrospective accounts of chronometers in the Pacific partly because they reinforced notions of a fundamental contrast between the legitimate propertied culture of the European mariners and the defects of Polynesian sociality. Such appropriations of precious and precise devices were used to reinforce this crucial contrast. But it is important to recognize the topography in which these devices found their place. If, as has been influentially suggested, "in the Pacific Cook had to play at being as best he could Adam Smith's god”, imposing laws of market commodities where their writ did not run, then it becomes important to understand how his instruments might occupy a role in this theodicy (Smith, 1992: 208-209). Polynesians avidly collected European materials while European mariners sought indigenous artefacts: this was exactly why Banks supposed the Endeavour's crewmen had taken the Bird quadrant and how exchanges functioned in Polynesian encounter. The high status objects offered to Cook and his fellows in Polynesia may have been designed better to integrate the British into carefully woven Polynesian networks of temporality and sociability. As a voyager with Cook in the South Seas in the 1770 s, the radical philosopher Georg Forster straightforwardly assumed that Polynesian taste for certain goods was but a version of occidental consumerism, rather than a key aspect of different islanders' cosmologies. This was clearly a conflict about devices to produce beliefs. Forster earned a living across Europe by marketing these Pacific goods to wealthy patrons. The Tuscan Grand Duke was offered Tahitian tapa cloth from which to make garments, alongside herbaria, weapons, carvings, and tools (Dawson, 1979: 13-14; Thomas, 2003: 231-232; Sahlins, 1988: 5). With Cook's Resolution at Queen Charlotte Sound in February 1777, the surgeon David Samwell reckoned the vessel "might be called a second Noah's Ark", its variegated cargo astonishing the Maori while "familiaris[ing] the Savage Scene". Samwell added that the price of Maori artefacts had risen remarkably: "every one was so flush of Trade that they sold their Instruments of War \& every thing they brought to Market at 
a very high price". ${ }^{8}$ Back in London, Samwell was courted by enthusiastic naturalists and entrepreneurs, sold much of his own collection at auction in 1781, while claiming that it was Banks who'd monopolised most of the materials gathered on the voyage (Kaeppler, 1978: 38, 40; Thomas, 2007). In such collections, the challenges of scope, of order and of meaning were closely entwined: too many things, too hard to classify, with different senses in different cultures.

It's worth reflecting, finally, on the ways in which European and Oceanic temporal artefacts found themselves juxtaposed and, by implication, connected in the metropolitan showrooms: these were precisely the sites where questions whether different cultures were coeval, or developmental, were worked out and defined. Many of the voyaging astronomers were active collectors and entrepreneurs of an entire range of time machines. In September 1775, for example, Maskelyne's assistant the mathematics teacher and almanac maker Reuben Burrow spent many days talking with Bayly and Wales in London in the wake of their Pacific voyages, not entirely amiably. But despite his inveterate loathing of Wales as rival and critic, Burrow proved himself fascinated by the curious artifacts the astronomer brought back from Tahiti and Aotearoa-New Zealand (Wilkinson, 1853: 192). This was a moment when the metropolis was especially possessed by interest in the temporal significance of material culture for judgment of the worth of European and Polynesian societies, not least because the voyage brought with it the dispossessed Raiatean landowner Mai, who reached London in July 1774. It was reported that Mai had sought resources from British armaments and instruments to reclaim Raiatea from its Borabora conquerors. Banks provided him with an electrical machine, a cynosure of up-to-date enlightened and showy instrumentation designed to impress primitive audiences. Mai's accumulation of London goods and their fate when he returned with Cook to Polynesia in 1777 was much discussed by analysts of social progress and its vagaries, such as Forster. Several waspishly remarked on the inutility and triviality of these European artifacts (Hetherington, 2001: 3; Thomas, 2003: 347-348; Guest, 2007: 149152, 157-159; Hackforth-Jones, 2007: 20; Fullagar, 2012: 127). According to Bayly, present as astronomer on Cook's third voyage during the return to Huahine in October 1777, Mai "entertained the Chiefs and principal women with his organ and electrical machine, which worked tolerable well". At the same time, however, a Borabora man took a sextant from Bayly's observatory, while Mai acted to recover the instrument. Cook, Smith's god, decided to shave the man's head and cut off his ears as "a public and severe example" (Beaglehole, 1967: 236-237).

This was by no means the only telling chronological juxtaposition of Polynesian material culture with scientific and philosophical hardware. In London, "natural and artificial curiosities lately brought home with Omia

8. Newell, 2003: 248; Samwell's journal, 13 February 1777, in Beaglehole, 1967: 995. 
[Mai]", including Maori patu, Tongan wooden pillows, Tahitian bark cloth and "a curious dress of Omia as represented in his print", were all put on show at Christopher Pinchbeck's Repository. These objects are not now identifiably extant, but some might tentatively be linked with "Omai relics" held at the Maritime Museum in Sydney. ${ }^{9}$ Exceptionally telling is that Pinchbeck was a celebrated London clock maker, a master of time machines famed for his manufacture of a Panopticon musical clock displaying half a dozen scenes of vividly automated mundane labour in shipyards and foundries, masons' yards and smithies. He presided over London's Society of Engineers and chaired a mechanics committee for the Society of Arts. It made sense to put side by side an exemplary metropolitan clock that embodied the entire range of social technologies pursued in the capital with the temporally defined devices brought from Polynesia. It is of considerable significance, therefore, that Pinchbeck's show artfully juxtaposed and combined a range of machines, balances, clocks, and mechanical models, alongside his own Musical Panopticon, with the range of "artificial curiosities" from the Polynesian voyage, "the whole form'd without the use of instruments made of Iron or any Metal whatsoever by the ingenious Natives of that part of the world" (Shenton, 1976; Altick, 1978: 60, 86, 429; Pérez, 2008: 31-34). Pinchbeck's publicity linked these artificial curiosities with Tobias Furneaux, commander of the Adventure, and with Mai quite directly. It also made sure to link them with his curious and pleasant "Mechanical exhibition", and thus to invite explicit comparison of the contemporary arts of Polynesia with the engines and mobile instruments of London. This was by no means a straightforward nor an innocent coupling, but it is eloquent about the various places occupied by the materials of navigation, technique and artifice at this conjuncture.

Pinchbeck's catalogue presupposed the worth of intimate encounter between an entire range of ingenuities, tools and mechanics. In the wake of Adam Smith, whose writings on commercial expansion and the passions of consumption attended closely to this encounter, it was held by the authors of the range of inventories and catalogues that flooded the market for curios and instruments in late eighteenth century London that the elegance and ingenuity of the means by which an artefact had been made and secured mattered more than its immediate use. These virtues were exactly how the place of any culture on the developmental time scale would be defined. One was to admire the fitness of design of such curious devices and the extraordinary ingenuity and energy required to fetch them from remote islands, rather than treat them as mere utilities. The economist made the point by reflecting on how the European time sense was embodied in a taste for exquisite time machines. Smith explained that "a watch that falls behind above two minutes a day is despised by one curious in watches". But, according to the Scottish professor, even though

9. A catalogue and description of a great variety of natural and artificial curiosities...lately brought home with Omia (London, 1774), KRO 0002 in Kroepelien Collection, Kon Tiki Museum, Oslo. Compare Gapps 2009; Kaeppler, 1978: 44. 
the "sole use of watches is to tell us what o'clock it is", users and owners of fine watches "will not always be found more scrupulously punctual than other men". Rather, he concluded, "what interests him is not so much the attainment of this piece of knowledge as the perfection of the machine which serves to attain it" (Smith, 1759: 340-341). ${ }^{10}$

This throws a somewhat different light on the supposedly Smithian agency of the commodity culture through which travelling instruments and artificial curiosities moved around and between the Pacific and Europe in the later eighteenth century, and then allegedly allowed field scientists to move back in time when they moved out from Europe. What was juxtaposed at Pinchbeck's show or De Gérando's study, or encountered together at Greenwich, Gizeh, Sydney, Tanna or Tahiti, was a set of complicated judgements of what counted as perfection of means and design, and thus of a moral purpose and a degree of social and historical development. The devices of time travel were never so weak that their meanings changed entirely as they moved across the globe; nor were they ever so potent that they imposed a singular time spirit everywhere they went. Such machines did embody robust and specific beliefs about temporality yet such machines only worked because of their circulation in and between heterogeneous networks. The aim of this essay has been to explore the consequences of that fascinating balancing act: thus to work out what was literal and what if anything was metaphorical about Henry Maine's celebrated and ghastly image, cited as the epigraph of this paper, of colonial power and the variability of time (Johnson, 1991: 387).

Simon ScHAFFeR

University of Cambridge

sjs16@cam.ac.uk

10. See Pérez (2008: 27-28) and Guest (2007: 152-153), who both cite these pages from Smith. 


\section{Bibliography}

Altick Richard, 1978, The Shows of London, Cambridge, MA, Harvard.

BeAglehole John Cawte (ed.), 1961, The voyage of the Resolution and Adventure, 1772-1775, Cambridge, Cambridge University Press.

- (ed.), 1963, The Endeavour Journal of Joseph Banks 1768-1771, Sydney, Angus and Robertson, (2 $2^{\text {nd }}$ ed. $)$.

- (ed.), 1967, The Voyage of the Resolution and Discovery 1776-1780, Cambridge, Cambridge University Press.

Buschmann Rainer, 2014, Iberian visions of the Pacific Ocean, London, Palgrave.

Davison Graeme, 1993, The unforgiving minute: how Australia learned to tell the time, Melbourne, Oxford University Press.

DAwson Ruth, 1979, "Collecting with Cook: the Forsters and their artifact sales", Hawaiian Journal of History, 13, p. 5-16.

Desporx Philippe, 2005, Le monde mesuré: dispositifs de l'exploration à l'âge des Lumières, Genève, Droz.

Douglas Bronwen, 2014, Science, voyages and encounters in Oceania, London, Palgrave.

DunN Richard and HiggitT Rebekah, 2014, Ships, clock and stars: the quest for longitude, London, Collins.

FABIAN Johannes, 2002 [1983], Time and the other: how anthropology makes its object, New York, Columbia University Press.

Fornasiero Jean, Monteath Peter and West-Sooby John, 2004, Encountering Terra Australis: the Australian voyages of Nicolas Baudin and Matthew Flinders, Kent Town, SA, Wakefield Press.

Fullagar Kate, 2012, The savage visit: new world people and popular imperial culture in Britain, 1710-1795, Berkeley, University of California Press.

GAPPs Stephen, 2009, “Omai relics from the Furneaux collection”, Signals, 89, p. 10-15.

Gellner Ernest, 1964, Thought and change, Chicago, Chicago University Press.

-, 1998, Language and solitude, Cambridge, Cambridge University Press.

GÉrANDO Joseph-Marie de, 1994, "Considérations sur les diverses méthodes à suivre dans l'observation des peuples sauvages ", in J. Copans and J. Jamin (ed.), Aux origines de l'anthropologie française, Paris, Jean-Michel Place, p. 73-109.

Glennie Paul and Thrift Nigel, 2009, Shaping the day: a history of timekeeping in England and Wales 1300-1800, Oxford, Oxford University Press.

Green Charles and Cook James, 1771, "Observations made by appointment of the Royal Society at King George's Island in the South Sea", Philosophical Transactions, 61, p. 397-421.

GruZINSKI Serge, 2010, What time is it there? America and Islam at the dawn of modern times, Cambridge, Polity Press.

Guest Harriet, 2007, Empire, Barbarism and Civilisation: Captain Cook, William Hodges and the return to the Pacific, Cambridge, Cambridge University Press.

Hackforth-Jones Jocelyn, 2007, "Mai/Omai in London and the South Pacific", in J. Sofaer (ed.), Material Identities, Oxford, Blackwell, p. 14-30.

HARRIS Steven J., 1998, “Long-Distance corporations, Big Sciences and the geography of knowledge”, Configurations, 6, p. 269-304. 
Hetherington Michelle, 2001, “The cult of the South Seas”, in M. Hetherington (ed.), Cook and Omai: the cult of the South Seas, Canberra, National Library of Australia, p. 1-7.

Howse Derek, 1969, “Captain Cook's marine timekeepers - the Kendall watches”, Antiquarian Horology, 6, p. 190-205.

Howse Derek and Hutchinson Beresford, 1969, "The saga of the Shelton clocks", Antiquarian Horology, 6, p. 281-298.

Hughes Miranda, 1990, “The dynamometer and the Diemenese”, in H. Le Grand (ed.), Experimental enquiries, Dordecht, Kluwer, p. 81-98.

Нumboldt Alexander von and BonPLANd Aimé, 1814, Personal narrative of travels to the equinoctial regions, London, Longman.

Johnson Gordon, 1991, "India and Henry Maine", in A. Diamond (ed.), The Victorian achievement of Sir Henry Maine, Cambridge, Cambridge University Press, p. 376-388.

Kaeppler Adrienne, 1978, Artificial curiosities, Honolulu, Bishop Museum.

LAtour Bruno, 1991, Nous n'avons jamais été modernes, Paris, La Découverte.

LaURIE Philip S., 1988, “William Dawes and Australia's first observatory”, Quarterly Journal of the Royal Astronomical Society, 29, p. 469-482.

LÉvi-STrauss Claude, 1966, "Anthropology: its achievements and future", Current anthropology, 7, p. 124-127.

Livingstone David, 1857, Missionary travels and researches in south Africa, London, John Murray.

McNeIL Rod, 2001, "Time after time: temporal frontiers and boundaries in colonial images of the Australian landscape”, in L. Russell (ed.), Colonial frontiers, Manchester, Manchester University Press, p. 47-65.

Moravia Sergio, 1967, "Philosophie et géographie à la fin du $18^{\mathrm{e}}$ siècle", Studies in Voltaire and the eighteenth century, 57, p. 937-1011.

NANNI Giordano, 2012, The colonisation of time: ritual, routine and resistance in the British empire, Manchester, Manchester University Press.

Nathan David (ed.), 2009, William Dawes' notebooks on the aboriginal languages of Sydney 1790-1791, London, SOAS.

Newell Jennifer, 2003, "Irresistible objects: collecting in the Pacific and Australia in the reign of George III", in K. Sloan (ed.), Enlightenment: discovering the world in the eighteenth century (London: British Museum, p. 246-257

-, 2010, Trading nature: Tahitians, Europeans, and ecological exchange, Honolulu, University of Hawai'I Press.

Pérez Liliane, 2008, "Technology, curiosity and utility in England and France in the eighteenth century", in B. Bensaude-Vincent and C. Blondel (ed.), Science and Spectacle in the European Enlightenment, Aldershot: Ashgate, p. 25-42.

Perkins Maureen, 2001, The reform of time: magic and modernity, London, Pluto Press.

PÉron François, 1994, «Expériences sur la force physique des peoples sauvages", in J. Copans and J. Jamin (eds.), Aux origines de l'anthropologie française, Paris, Jean-Michel Place, p. 179-200.

RAJ Kapil, 2000, " $18^{\text {th }}$ century Pacific voyages of discovery, 'big science', and the shaping of a European scientific and technological culture", History and technology, 17, p. 79-98.

SAHLins Marshall, 1988, "Cosmologies of capitalism: the trans-Pacific sector of the 'world-system'”, Proceedings of the British Academy, 74, p. 1-51. 
Salmond Anne, 2005, "Their body is different, our body is different: European and Tahitian navigators in the $18^{\text {th }}$ century", History and Anthropology, 16, p. 167-86. SeEd Patricia, 1995, Ceremonies of Possession in Europe's Conquest of the New World, Cambridge, Cambridge University Press.

Shenton Rita, 1976, Christopher Pinchbeck and his family, Asford, Brant Wright.

Sмiтн Adam, 1759, Theory of moral sentiments, London, Millar.

Sмiтн Bernard, 1985, European vision and the South Pacific, New Haven, Yale University Press, $2^{\text {nd }}$ edition.

-, 1992, Imagining the Pacific: in the Wake of the Cook Voyages, New Haven, Yale.

Sмiтн Vanessa, 2010, Intimate strangers: friendship, exchange and Pacific encounters, Cambridge, Cambridge University Press.

STOcking George, 1964, "French anthropology in 1800", Isis, 55, p. 134-50.

STRATHERN Marilyn, 1990, "Artifacts of history: events and the interpretation of images", in J. Siikala (ed.), Culture and history in the Pacific, Helsinki, Finnish Anthropological Society, p. 25-44.

Subrahmanyam Sanjay, 1993, The Portuguese Empire in Asia 1500-1700, London, Longman.

Svet Yakov and Fedorova Svetlana, 1978, "Captain Cook and the Russians”, Pacific studies, 2, p. 1-19.

Thомаs Nicholas, 2003, Discoveries: the voyages of Captain Cook, London, Allen Lane. -, 2007, "David Samwell, Pacific ethnographer and historian", in D. Samwell, The death of Captain Cook and other writings, ed. M. Fitzpatrick, N. Thomas and J. Newell, Cardiff, University of Wales Press, p. 41-57.

Turnbull David, 1998, "Cook and Tupaia: a tale of cartographic méconnaissance?”, in M. Lincoln (ed.), Science and Exploration in the Pacific, Woodbridge, Boydell, p. 117-132.

WALES William and BAYLY William, 1777, The original astronomical observations made in the course of a Voyage towards the Soub Pole and round the World, London, Strahan.

Werrett Simon, 2004, "Russian responses to Cook", in Glyndwr Williams (ed.), Captain Cook: explorations and reassessments, Woodbridge, Boydell, p. 179-197.

Wilkinson T.T., 1853, “The journals of the late Reuben Burrow”, Philosophical magazine, $4^{\text {th }}$ series, 5, March, p. 185-193. 


\section{Traveling Machines and Colonial Times}

In colonial and cross-cultural encounters, different time-scales and variable means for registering time's passage come into relation with each other, often deliberately. An important and aggressive tradition supposed that distant and exotic cultures were to be understood as belonging to remote and antique pasts. The use and fate of devices designed to register time within these encounters therefore become significant for a better understanding of what has been at stake in the challenges to knowledge and to belief that emerge in such encounters. The example of British maritime entry into the Pacific in the eighteenth century offers clear cases where different time-senses were reorganized and a range of time-machines were challenged in the complex practical worlds that emerged in relations between different cultures.

Key-words: chronometer, temporality, Pacific Ocean, sextant, exploration.

\section{Machines de voyage et temps coloniaux}

Dans les rencontres coloniales et interculturelles, différentes échelles de temps et des moyens variables pour enregistrer le passage du temps entrent en relation, souvent délibérement. Une tradition importante, et agressive, supposait que les cultures lointaines et exotiques devaient être comprises comme appartenant à des passés lointains et antiques. L'utilisation et le destin d'appareils conçus pour enregistrer le temps lors de ces rencontres deviennent donc des éléments importants pour une meilleure compréhension des enjeux, des défis, des savoirs et des croyances qui émergent de telles rencontres. L'exemple de l'entrée maritime britannique dans le Pacifique au XVIII siècle offre des exemples clairs de réorganisation des différents sens du temps et de remise en question de diverses machines à mesurer le temps, au sein des mondes pratiques complexes qui ont émergé des relations entre différentes cultures.

Mots clefs: chronomètre, temporalité, Océan Pacifique, sextant, exploration.

\section{Maquinas de viaje y tiempos coloniales}

En los encuentros coloniales e interculturales, diferentes escalas de tiempo $y$ medios variables para registrar el paso del tiempo se relacionan entre sí, a menudo deliberadamente. Una tradición importante y agresiva suponía que las culturas distantes y exóticas debian entenderse como pertenecientes a pasados remotos y antiguos. El uso y el destino de los dispositivos diseñados para registrar el tiempo dentro de estos encuentros, por lo tanto, se vuelven significativos para una mejor comprensión de lo que ha estado en juego en los desafios al conocimiento y la creencia que surgen en tales encuentros. 
I9O - ARChIVES DE SCIENCES SOCIALES DES RELIGIONS

El ejemplo de la entrada maritima británica en el Pacífico en el siglo XVIII ofrece casos claros en los que se reorganizaron diferentes sentidos del tiempo y se desafió una gama de máquinas del tiempo en los complejos mundos prácticos que surgieron en las relaciones entre diferentes culturas.

Palabras claves: cronómetro, temporalidad, Océano Pacifico, sextante, exploración. 